\title{
PROBLEM BASED LEARNING DIPADU JIGSAW BERBASIS LESSON STUDY: UPAYA PEMBERDAYAAN LITERASI INFORMASI MAHASISWA BIOLOGI DI ERA DIGITAL
}

\author{
Ummi Nur Afinni Dwi Jayanti \\ Universitas Islam Negeri Sumatera Utara \\ ummiafinni@uinsu.ac.id
}

\begin{abstract}
ABSTRAK
Untuk dapat belajar secara efektif di lingkungan pendidikan tinggi, mahasiswa perlu melek informasi melalui cara yang sesuai dengan lingkungan akademik dan disiplin ilmu yang mereka pelajari, termasuk di bidang biologi. Walaupun demikian, kurikulum pendidikan tinggi di Indonesia belum secara sengaja mengintegrasikan pengembangan literasi informasi dalam pembelajaran dikelas dan kegiatan praktikum. Penelitian ini bertujuan untuk mengetahui sejauh mana model pembelajaran problem-based learning dipadu jigsaw yang diterapkan dalam perkuliahan Fisiologi Hewan dapat meningkatkan keterampilan literasi mahasiswa biologi. Penelitian ini menggunakan desain penelitian tindakan kelas berbasis Lesson Study. Empat puluh mahasiswa program studi biologi berpartisipasi dalam studi ini. Keterampilan literasi informasi mahasiswa diukur dengan tes literasi informasi yang mengacu pada Association of College and Research Libraries. Hasil penelitian menunjukkan intervensi yang dilakukan memfasilitasi penguasaan keterampilan mahasiswa untuk mengidentifikasi, mengevaluasi dan menggunakan informasi secara efektif untuk merumuskan solusi pemecahan masalah yang ada. Namun belum secara signifikan memfasilitasi penguasaan indikator mengakses informasi secara efektif dan efisien serta memahami isu ekonomi, hukum, dan sosial terkait penggunaan informasi. Temuan penelitian ini dapat dijadikan sebagai salah satu informasi bagi pendidik perguruan tinggi terkait intervensi yang dapat dirancang untuk mengembangkan literasi informasi mahasiswa. Pendidik dalam konteks pendidikan tinggi perlu mengintegrasikan aktivitas pemecahan masalah secara berkesinambungan dalam perkuliahan sebagai upaya pengembangan keterampilan literasi informasi mahasiswa. Modifikasi rancangan intervensi dalam penelitian ini dianjurkan untuk dilakukan agar dapat menyempurnakan hasil yang diharapkan.
\end{abstract}

Kata Kunci: Lesson Study, Literasi Informasi, Pembelajaran Kooperatif, Problem-Based Learning

\begin{abstract}
To learn effectively in a higher education environment, students need to be information literate. In particular, they must be information literate in a way that is appropriate to their academic background and disciplines, including biology. However, the higher education curriculum in Indonesia has not intentionally integrated the development of information literacy in classroom learning and laboratory activities. This study aims to determine the extent to which the problembased learning model combined with a jigsaw applied in Animal Physiology lectures can improve the information literacy skills of biology students. This study employed a Lesson Study based-class action research. Forty biology students participated in this study. Research instrument used an information literacy test that refers to the Association of College and Research Libraries. The results showed that the intervention facilitated the development of students' mastery in identifying, developing, and using information effectively to formulate existing problem-solving solutions. However, it has not significantly facilitated mastery in accessing information effectively and efficiently and understanding the economic, legal, and social issues related to the use of information. The findings of this study can be used as information for tertiary educators' related interventions that can be designed to develop student information literacy. Educators in tertiary education need to gradually integrate problem-solving activities in their lectures as an effort to develop students' information literacy. Design modifications are expected to be better done to improve the desired results.
\end{abstract}

Keywords: Lesson Study, Information Literacy, Cooperative Learning, Problem-Based Learning 


\section{PENDAHULUAN}

Literasi informasi merupakan elemen dasar dan vital bagi dunia pendidikan (Freeman \& Lynd-Balta, 2010). Literasi informasi merujuk pada keterampilan untuk mengidentifikasi, menemukan, memahami, mengevaluasi dan menggunakan informasi untuk menghasilkan pengetahuan baru dan berpartisipasi secara etis dalam komunitas belajar (ACRL, 2000; Middle State Commission of Higher Education, 2003). Borchardt et al. (2018) berargumen bahwa pengembangan keterampilan literasi informasi menjadi tujuan pembelajaran yang penting pada konteks pendidikan tinggi sebagai bentuk persiapan dan tahap awal memulai dunia ilmiah.

Mahasiswa di berbagai program sarjana, termasuk di bidang biologi, diharapkan dapat menggunakan keterampilan literasi informasi dalam menulis laporan praktikum, menulis paper dan mengembangkan hipotesis yang dapat diuji. Harwood (2004) menambahkan bahwa kemampuan mengumpulkan informasi merupakan bagian esensial dari penyelidikan ilmiah. Hal ini didukung dengan peningkatan jumlah artikel jurnal penelitian dalam beberapa tahun terakhir bidang sains yang dapat digunakan sebagai sumber informasi penelitian (Freeman \& Lynd-Balta, 2010). Dengan demikian, integrasi literasi informasi dalam kurikulum sains menjadi penting untuk dilakukan.

Matakuliah Fisiologi Hewan dan Manusia merupakan matakuliah wajib bagi mahasiswa S1 Program Studi Biologi di salah satu universitas negeri di Jawa Timur. Perkuliahan Fisiologi Hewan dan Manusia umumnya menggunakan strategi ceramah (Amin et al.,, 2017; Wahyuni, 2015), penggunaan Lembar Kegiatan Mahasiswa (LKM) (Ningsih et al., 2020), tutorial revisi kelompok kecil (small-group revision tutorial) dan penentuan bacaan (prescribed reading) (Chevins, 2005). Berdasarkan hasil observasi yang dilakukan peneliti, diketahui bahwa kegiatan pembelajaran Fisiologi Hewan dan Manusia dibagi menjadi dua yaitu teori dan praktikum. Metode pembelajaran teori yaitu diskusi dan presentasi dimana seminggu sebelum proses pembelajaran mahasiswa diberikan LKM yang berisi pertanyaan kemudian dipilih kelompok secara acak untuk mempresentasikan jawaban saat kegiatan perkuliahan teori.

Hasil observasi pada kegiatan perkuliahan teori Fisiologi Hewan dan Manusia memperlihatkan beberapa mahasiswa sulit untuk mengomunikasikan gagasan atau pendapatnya dengan baik dan jelas. Beberapa mahasiswa juga terlihat kurang terlibat dalam kegiatan diskusi. Selain itu, analisis informasi jawaban LKM yang dipresentasikan mahasiswa menunjukkan masih kurangnya kemampuan mahasiswa dalam mengolah informasi dari berbagai sumber dengan baik. Hal ini terlihat dari jawaban yang dipresentasikan mahasiswa masih menyalin jawaban LKM mahasiswa tahun sebelumnya yang diunggah di website file hosting. Berdasarkan hasil tersebut, diasumsikan keterampilan berpikir kritis mahasiswa yang tercermin dari pengolahan informasi jawaban LKM masih rendah. Permasalahan ini diasumsikan terkait dengan rendahnya literasi informasi mahasiswa.

Selanjutnya, tes awal literasi informasi berdasarkan indikator ACRL (2000) dilakukan sebagai tindak lanjut dari hasil observasi awal. Hasil analisis menunjukkan 55\% mahasiswa mempunyai kategori mengetahui; 33\% mahasiswa berada pada kategori pengetahuan terbatas; $13 \%$ mahasiswa berada pada kategori sangat mengetahui; dan $0 \%$ untuk masingmasing kategori pengetahuan sangat terbatas maupun sangat banyak mengetahui. Data ini memberikan gambaran bahwa secara umum mahasiswa memiliki keterampilan literasi informasi yang cukup baik karena sebagian besar masuk dalam kategori mengetahui.

Namun, hasil analisis lebih lanjut terhadap lima indikator literasi informasi menurut ACRL (2000) menunjukkan bahwa persentase setiap indikator masih sangat rendah yaitu indikator mengidentifikasi informasi yang dibutuhkan sebesar 6,1\%; mengakses informasi yang 
dibutuhkan secara efektif dan efisien sebesar 8,75\%. Indikator mengevaluasi informasi dan sumber dengan kritis dan menggabungkan informasi sebesar 10,14\%; menggunakan informasi secara efektif untuk mencapai tujuan tertentu sebesar 9,16\%; dan memahami isu ekonomi, hukum dan sosial seputar penggunaan informasi dan menggunakan informasi secara etis dan legal sebesar 10,28\%.

Pertanyaan-pertanyaan di LKM juga tidak secara eksplisit memberikan tuntutan untuk mencari berbagai sumber yang relevan sehingga mahasiswa belum terlatih untuk mengembangkan kemampuan untuk mencari dan memilih berbagai macam informasi melalui sumber yang relevan sehingga mahasiswa hanya mengambil tanpa mengevaluasi informasi. Padahal mahasiswa yang literat informasi dan pemikir kritis akan dapat menentukan informasi yang relevan (Wallace \& Jefferson, 2013), menganalisis (Horton, 2007), mengevaluasi (ACRL, 2000) dan mensintesis informasi (SCONUL, 2011) tersebut untuk tujuan pembuatan tugas.

Berdasarkan permasalahan yang telah diuraikan maka solusi yang dapat ditempuh yaitu dengan menggunakan strategi pembelajaran yang tepat. Horton (2007) berargumen bahwa literasi informasi dapat ditingkatkan dengan menerapkan pedagogis aktif misalnya melalui pembelajaran berbasis masalah. Problem Based Learning (PBL) merupakan sebuah model pembelajaran yang didasarkan pada prinsip bahwa masalah dapat digunakan sebagai titik awal untuk mendapatkan atau mengintegrasikan pengetahuan baru (Wenger, 2014). Fainburg (2009) menambahkan bahwa PBL secara alami menjalin keterampilan literasi informasi mahasiswa untuk mengisi kesenjangan pengetahuan mahasiswa dan untuk mengaktifkan kreativitas mereka. Penggunaan Problem Based Learning untuk meningkatkan keterampilan literasi informasi mahasiswa telah banyak dilakukan akan tetapi masih terbatas pada matakuliah Kimia Organik (Shultz \& Li, 2015) dan program yang diadakan oleh perpustakaan kampus seperti studi yang dilakukan oleh Carder, Willingham \& Bibb (2001), Cook \& Walsh (2012) serta Diekema, Holliday \& Leary (2011). Belum banyak studi yang mengkaji penerapan Problem Based Learning untuk meningkatkan literasi informasi mahasiswa pada materi biologi khususnya Fisiologi Hewan dan Manusia.

Pada penelitian ini, model $P B L$ dipadu dengan model pembelajaran Jigsaw. Pembelajaran Kooperatif Jigsaw melibatkan siswa secara aktif belajar dalam suasana kelompok untuk memecahkan masalah belajar dan memiliki rasa tanggungjawab terhadap pembelajarannya sendiri dan juga pembelajaran orang lain. Siswa tidak hanya mempelajari materi yang diberikan tetapi mereka juga bertanggungjawab untuk mengajarkan materi tersebut. Kenney (2008) berargumen bahwa pengalaman belajar aktif yang bergantung pada kolaborasi, berpikir kritis dan interaksi hands-on dengan sumber pembelajaran merupakan langkah ideal untuk mengembangkan keterampilan literasi informasi. Pembelajaran kooperatif Jigsaw telah digunakan untuk mengembangkan keterampilan literasi informasi seperti yang dilakukan oleh Perpustakaan Universitas Campbell (Epss \& Taxakis, 2015). Adawiyah, Susilo, \& Indriwati (2019) menerapkan pembelajaran untuk meningkatkan literasi informasi siswa menengah. Namun belum banyak penelitian yang mengkaji penggunaan jigsaw pada matakuliah sains di konteks perguruan tinggi. Selain itu, penelitian terdahulu melaporkan bahwa kombinasi $P B L$ dan Jigsaw dapat meningkatkan kemampuan berpikir kritis siswa (Karmana, 2010; Nurmala et al., 2015) serta kesadaran metakognitif, pemecahan masalah dan hasil belajar (Karmana, 2010). Namun, belum banyak penelitian yang mengkaji pengembangan keterampilan literasi informasi melalui $P B L$ dipadu jigsaw khususnya dalam konteks pendidikan tinggi.

Dalam rangka meningkatkan kualitas pembelajaran, pendidik memegang peranan penting. Salah satu terobosan untuk 
meningkatkan kualitas pendidik yaitu dengan melakukan kegiatan Lesson Study. Hendayana (2006) berargumen bahwa Lesson Study merupakan suatu model pembinaan profesi pendidik melalui pengkajian pembelajaran secara kolaboratif dan berkelanjutan berlandaskan prinsip kolegalitas dan mutual learning untuk membangun komunitas belajar. Dengan demikian, Lesson Study bukan metode atau strategi pembelajaran tetapi kegiatan Lesson Study dapat menerapkan berbagai metode strategi pembelajaran yang sesuai dengan situasi, kondisi, dan permasalahan yang dihadapi pendidik.

Berdasarkan paparan latar belakang diatas, penelitian ini bertujuan untuk mengetahui sejauh mana penerapan model $P B L$ dipadu jigsaw berbasis Lesson Study dapat meningkatkan literasi informasi mahasiswa. Hasil penelitian ini diharapkan dapat memberikan praktik empiris berkaitan dengan model pembelajaran yang dapat memfasilitasi pengembangan literasi informasi mahasiswa.

\section{METODE}

Desain penelitian yang digunakan pada studi ini yaitu penelitian tindakan kelas. Studi ini digunakan untuk menilai sejauh mana perlakuan yang diterapkan dalam perkuliahan Fisiologi
Hewan dapat meningkatkan kemampuan literasi mahasiswa biologi. Hopkins (2008) berargumen bahwa tujuan utama dari desain penelitian tindakan kelas yaitu untuk meningkatkan aspek praktik di dalam kelas.

Desain penelitian tindakan kelas mengacu pada model Kemmis \& Taggart (1988) yang terdiri atas empat komponen, yaitu: (1) perencanaan, yang mencakup penyusunan instrument pembelajaran dan instrumen penelitian; (2) pelaksanaan tindakan, dilakukan berbasis Lesson Study meliputi tahapan plan, do dan see; (3) observasi dan (4) refleksi. Pada tahapan plan, dirumuskan integrasi antara sintaks model pembelalajaran $P B L$ dan Jigsaw. Sintaks model PBL maupun Jigsaw merujuk pada Rusman (2010). Integrasi kedua model tersebut dapat dilihat pada Tabel 1.

Partisipan dalam penelitian ini merupakan mahasiswa biologi di salah satu universitas negeri di Jawa Timur berjumlah 40 mahasiswa, terdiri dari 6 putra dan 34 putri. Teknik sampling yang digunakan yaitu purposive convenience sampling. Walaupun hasil penelitian ini tidak dapat digeneralisasikan, Lemons (2009) menegaskan bahwa solusi yang digunakan dapat diterapkan dalam konteks lain untuk mengevaluasi relevansinya di konteks yang berbeda.

Tabel 1. Integrasi Sintaks PBL dan Jigsaw

\begin{tabular}{|c|c|c|}
\hline \multicolumn{2}{|c|}{ Sintaks Pembelajaran } & \multirow{2}{*}{ Kegiatan Pembelajaran } \\
\hline PBL & Jigsaw & \\
\hline $\begin{array}{l}\text { Orientasi mahasiswa } \\
\text { pada masalah }\end{array}$ & Menyampaikan tujuan & $\begin{array}{l}\text { - Memberikan fenomena } \\
\text { - Merumuskan pertanyaan } \\
\text { - Menetapkan tujuan pembelajaran }\end{array}$ \\
\hline $\begin{array}{l}\text { Mengorganisasi } \\
\text { mahasiswa dalam } \\
\text { belajar }\end{array}$ & $\begin{array}{l}\text { - Menyajikan informasi } \\
\text { - Mengorganisasi } \\
\text { mahasiswa kedalam } \\
\text { kelompok belajar } \\
\end{array}$ & $\begin{array}{l}\text { - Membagi permasalahan untuk didiskusikan } \\
\text { - Membentuk kelompok belajar } \\
\text { - Membentuk kelompok asal dan kelompok ahli }\end{array}$ \\
\hline $\begin{array}{l}\text { Membimbing } \\
\text { penyelidikan individu } \\
\text { maupun kelompok }\end{array}$ & $\begin{array}{l}\text { - Membantu kerja } \\
\text { kelompok dalam belajar } \\
\text { - Mengetes materi }\end{array}$ & $\begin{array}{l}\text { - Mengumpulkan data pada kelompok ahli dan } \\
\text { mempresentasikan hasil diskusi } \\
\text { - Menetapkan solusi pada kelompok asal }\end{array}$ \\
\hline $\begin{array}{l}\text { Mengembangkan dan } \\
\text { menyajikan hasil karya }\end{array}$ & Memberikan penghargaan & $\begin{array}{l}\text { - Menyampaikan kesimpulan atau pokok-pokok } \\
\text { dari diskusi } \\
\text { - Menyampaikan masalah dan solusi } \\
\text { - Membrikan tanggapan hasil penyajian solusi }\end{array}$ \\
\hline $\begin{array}{l}\text { Menganalisis dan } \\
\text { mengevaluasi proses } \\
\text { pemecahan masalah }\end{array}$ & & - Melakukan refleksi dan konfirmasi \\
\hline
\end{tabular}


Pengumpulan data dilakukan menggunakan tiga metode sebagai bentuk triangulasi untuk memastikan kredibilitas data kualitatif yang didapatkan (Oliver-Hoyo \& Hallen, 2006). Metode pengumpulan data yang digunakan mencakup: tes literasi informasi mahasiswa, wawancara dan catatan lapangan hasil observasi proses pembelajaran. Tes literasi informasi dilakukan sebanyak tiga kali, yaitu tes pra siklus, tes akhir siklus I dan siklus II. Bentuk tes adalah tes pilihan ganda.

Analisis data dalam penelitian dimulai sejak awal sampai pengumpulan data. Teknis analisis yang digunakan dalam penelitian adalah deskriptif kualitatif mengacu pada model analisis Miles dan Huberman (Sugiyono, 2011) yang dilakukan dalam 3 tahapan yaitu reduksi data, penyajian data dan penarikan kesimpulan. Data kemudian dianalisis dengan cara sebagai berikut:

a. Analisis data keterlaksanaan pembelajaran dan Lesson Study

Analisis data hasil pengamatan kegiatan dosen model dan mahasiswa selama proses pembelajaran dan data hasil pengamatan Lesson Study, yaitu Plan, Do, dan See selama proses pembelajaran dengan menggunakan rumus sebagai berikut:

$$
\begin{aligned}
& \text { Persentase keterlaksanaan }= \\
& \frac{\text { Sindikator yang muncul }}{\text { इseluruh indikator }} \times 100 \%
\end{aligned}
$$

Persentase dan kriteria keterlaksanaan pembelajaran merujuk pada Arikunto (2009) seperti tertera pada Tabel 2 .

Tabel 2. Persentase dan kriteria keterlaksanaan pembelajaran

\begin{tabular}{cl}
\hline \% Keterlaksanaan & \multicolumn{1}{c}{ Kriteria } \\
\hline $80-100$ & Sangat terlaksana \\
\hline $66-79$ & Terlaksana \\
\hline $56-65$ & Cukup Terlaksana \\
\hline $40-55$ & Kurang Terlaksana \\
\hline $30-39$ & Sangat Kurang Terlaksana \\
\hline
\end{tabular}

(Sumber: Arikunto, 2009)

\section{b. Literasi Informasi}

Data skor rata-rata literasi informasi diperoleh dengan menggunakan rumus sebagai berikut:

$$
\text { Skor Rata-rata (NR) }=\frac{\text { Total Skor Perolehan }}{\text { Total Skor Maksimal }} \times 100
$$

Skor rata-rata kemudian diubah menjadi deskripsi kategori keterampilan literasi informasi menggunakan instrument pengukuran yang telah dimodifikasi oleh peneliti berdasarkan Tabel Distribusi Frekuensi Guilford. Hal ini dilakukan dengan cara membagi persentase tertinggi dengan lima karena terdapat lima kategori deskripsi literasi informasi. Hasil bagi yaitu 20 menjadi interval dari lima kategori yang dirumuskan. Skala kategori literasi informasi dapat dilihat pada Tabel 3.

Tabel 3. Tabel interpretasi kategori literasi informasi

\begin{tabular}{cl}
\hline \% Keterlaksanaan & \multicolumn{1}{c}{ Kriteria } \\
\hline $80-100$ & Sangat Banyak Mengetahui \\
\hline $66-79$ & Sangat Mengetahui \\
\hline $56-65$ & Mengetahui \\
\hline $40-55$ & Pengetahuan Terbatas \\
\hline $30-39$ & Pengetahuan Sangat Terbatas \\
\hline
\end{tabular}

(Sumber: Guilford, 1988)

\section{HASIL DAN PEMBAHASAN}

\section{Siklus I}

Tahapan siklus I dimulai dengan tahapan perencanaan instrumen penelitian berupa tes literasi informasi. Pada tahap pelaksanaan tindakan, dilakukan Lesson Study sebanyak tiga kali untuk tiga pertemuan tatap muka dengan menerapkan model PBL dipadu jigsaw. Rata-rata persentase skor keterlaksanaan tahapan Lesson Study untuk tahapan Plan, Do dan See secara berturut-turut yaitu 91,85\%, 82,47\% dan $83,56 \%$ dengan kriteria sangat terlaksana. Sementara itu, rata-rata skor keterlaksanaan tahapan PBL dipadu jigsaw sebesar 75,87\% dengan kriteria terlaksana.

Berdasarkan hasil penelitian tindakan, dilakukan pembahasan mengenai peningkatan kecakapan literasi informasi melalui penerapan Problem Based Learning (PBL) dipadu Jigsaw dan praktikum yang secara umum diukur menggunakan tes yang mengacu pada O'Neil (2005) dan Saefi (2017) dengan indikator literasi informasi mengacu pada ACRL (2000). Hasil analisis data dapat dilihat pada Gambar 1. 
Ummi Nur Afinni Dwi Jayanti, Problem Based Learning Dipadu Jigsaw Berbasis Lesson Study: Upaya Pemberdayaan Literasi Informasi Mahasiswa Biologi Di Era Digital

Jurnal Biolokus: Jurnal Penelitian Pendidikan Biologi Dan Biologi Vol.4 (1)

Berdasarkan Gambar 1, peningkatan persentase keterampilan literasi informasi mahasiswa pada kategori mengetahui sebesar $52,15 \%$ atau mengalami peningkatan sebesar $15 \%$ dari pra-siklus ke siklus I. Namun, kategori sangat mengetahui mengalami penurunan sebesar $15 \%$ dari pra-siklus ke siklus I. Sementara itu, persentase kategori pengetahuan terbatas tidak mengalami peningkatan maupun penurunan dari pra-siklus ke siklus I.

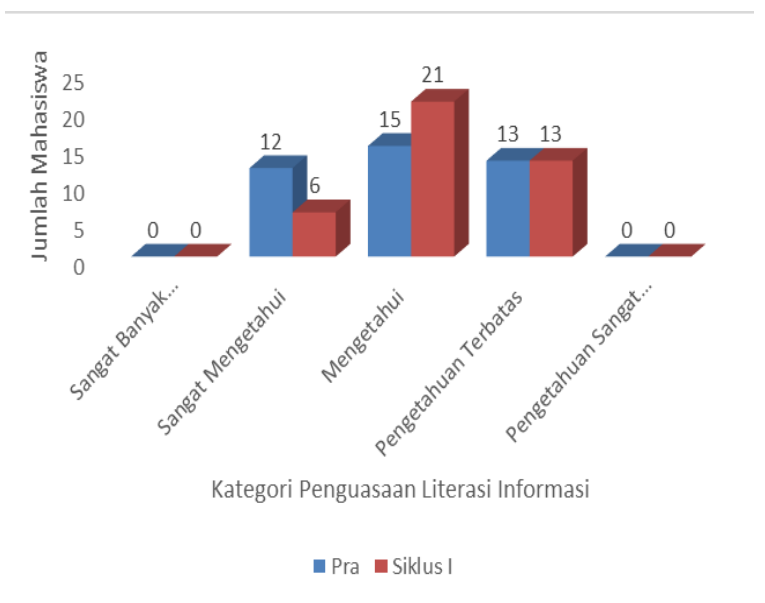

Gambar 1. Perbandingan kategori penguasaan literasi informasi mahasiswa pra-siklus dan siklus I.

Analisis lebih lanjut dilakukan pada kelima indikator literasi informasi seperti tersaji pada Gambar 2. Berdasarkan data pada Gambar 2, terjadi peningkatan persentase untuk indikator ketiga sebesar 5\%. Sementara itu terjadi penurunan persentase untuk indikator pertama, kedua, keempat dan kelima secara berturutturut sebesar 5\%, 15\%, 4,16\% dan 9,37\%

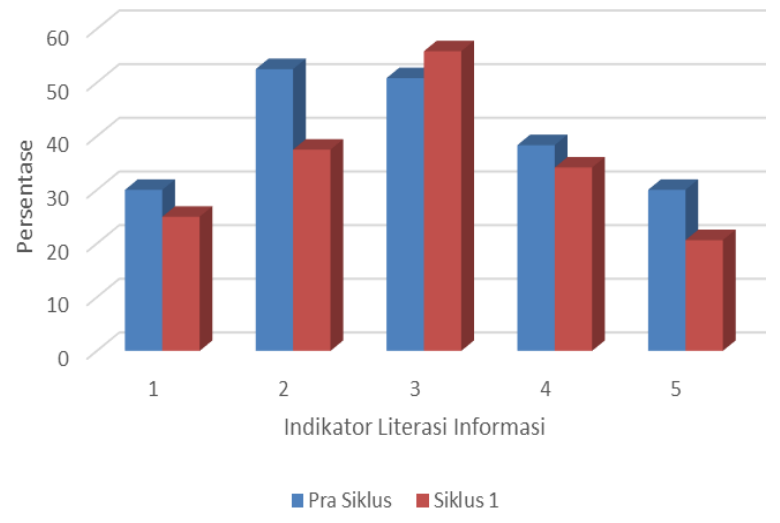

Gambar 2. Persentase penguasaan indikator literasi informasi dari pra-siklus ke siklus I.
Keterangan:

1 = mengidentifikasi informasi yang dibutuhkan

2 = mengakses informasi yang dibutuhkan secara efektif dan efisien

3 = mengevaluasi informasi dan sumber dengan krtis dan menggabungkan informasi yang dipilih menjadi dasar pengetahuan

4 = menggunakan informasi secara efektif untuk mencapai tujuan tertentu

5 = memahami isu ekonomi, hukum dan sosial seputar penggunaan informasi dan mengakses serta menggunakan informasi secara etis dan legal

Berdasarkan analisis data yang dipaparkan, dapat disimpulkan bahwa peningkatan keterampilan literasi informas pada siklus I belum signifikan dan belum mencakup semua indikator. Pelaksanaan siklus I mengalami sedikit kendala berupa pengelolaan waktu saat pembelajaran. Refleksi dan analisis siklus I menghasilkan kesimpulan bahwa tindakan berupa penerapan model pembelajaran Problem Based Learning dipadu Jigsaw belum memperlihatkan peningkatan pada keterampilan literasi informasi sehingga tindakan dilanjutkan pada siklus berikutnya. Keterampilan literasi informasi yang belum meningkat disebabkan oleh adanya lima mahasiswa yang tidak masuk perkuliahan dikarenakan sakit sehingga data antara pra-siklus dan siklus 1 tidak sebanding. Hasil refleksi siklus I berdasarkan Tabel 4 dijadikan panduan untuk membuat perencanaan tindakan pada siklus II.

Tabel 4. Hasil refleksi siklus i

\begin{tabular}{|c|c|c|}
\hline No & Refleksi & $\begin{array}{c}\text { Solusi untuk Perencanaan } \\
\text { Siklus II }\end{array}$ \\
\hline 1 & $\begin{array}{l}\text { LKM masih } \\
\text { kurang } \\
\text { dipahami, } \\
\text { terlalu sulit dan } \\
\text { membingung } \\
\text { kan }\end{array}$ & $\begin{array}{l}\text { - Menyederhanakan kegiatan } \\
\text { dan mengurangi permasalhan } \\
\text { yang diangkat dalam LKM } \\
\text { - Mengurangi tulisan atau } \\
\text { konten yang terlalu banyak di } \\
\text { LKM } \\
\text { - Memberikan pengarahan dan } \\
\text { penjelasan } \\
\text { mengerjakan LKM }\end{array}$ \\
\hline 2 & $\begin{array}{l}\text { Alokasi waktu } \\
\text { diskusi ahli dan } \\
\text { kelompok asal } \\
\text { kurang efisien }\end{array}$ & $\begin{array}{l}\text { - Membagi pembagian poin } \\
\text { diskusi sesuai kelompok } \\
\text { - Menyederhanakan dan } \\
\text { mengurangi konten di LKM }\end{array}$ \\
\hline 3 & $\begin{array}{l}\text { Mahasiswa } \\
\text { kurang siap } \\
\text { dengan media } \\
\text { presentasi }\end{array}$ & $\begin{array}{l}\text { - Mengarahkan mahasiswa } \\
\text { untuk mempersiapkan media } \\
\text { presentasi } \\
\text { - Memfasilitasi PPT, media, } \\
\text { gambar dan video dalam } \\
\text { kegiatan presentasi }\end{array}$ \\
\hline
\end{tabular}


Ummi Nur Afinni Dwi Jayanti, Problem Based Learning Dipadu Jigsaw Berbasis Lesson Study: Upaya Pemberdayaan Literasi Informasi Mahasiswa Biologi Di Era Digital

Jurnal Biolokus: Jurnal Penelitian Pendidikan Biologi Dan Biologi Vol.4 (1)

\begin{tabular}{|c|c|c|}
\hline No & Refleksi & $\begin{array}{c}\text { Solusi untuk Perencanaan } \\
\text { Siklus II }\end{array}$ \\
\hline 4 & $\begin{array}{l}\text { Mahasiswa aktif } \\
\text { bertanya saat } \\
\text { diskusi namun } \\
\text { sedikit bertanya } \\
\text { saat presentasi }\end{array}$ & $\begin{array}{l}\text { - Memberi reward kepada } \\
\text { mahasiswa yang aktif } \\
\text { bertanya } \\
\text { - Dosen membimbing jalannya } \\
\text { presentasi dan menyiapkan } \\
\text { materi dengan matang }\end{array}$ \\
\hline 5 & $\begin{array}{l}\text { Mahasiswa } \\
\text { tidak fokus } \\
\text { dalam } \\
\text { mengerjakan } \\
\text { tes siklus }\end{array}$ & $\begin{array}{l}\text { - Melaksanakan tes siklus pada } \\
\text { waktu yang tidak bersamaan } \\
\text { dengan UTS } \\
\text { - Berdiskusi dengan } \\
\text { mahasiswa untuk penentuan } \\
\text { waktu pelaksanaan tes }\end{array}$ \\
\hline
\end{tabular}

\section{Siklus II}

Tahapan siklus II dimulai dengan tahapan perencanaan instrumen pembeljaran berupa lembar monitoring keterlaksanaan Lesson Study dan pembelajaran Problem Based learning dipadu jigsaw, menentukan materi yang akan dibahas serta merencanakan perbaikan perencanaan tindakan pada siklus II sesuai dengan solusi pada Tabel 3. Pada tahap pelaksanaan tindakan, dilakukan Lesson Study sebanyak tiga kali untuk tiga pertemuan tatap muka dengan menerapkan model PBL dipadu jigsaw. Rata-rata persentase skor keterlaksanaan tahapan Lesson Study untuk tahapan Plan, Do dan See secara berturut-turut yaitu 93,87\%, 84,2\% dan $84,7 \%$ dengan kriteria sangat terlaksana. Sementara itu, rata-rata skor keterlaksanaan tahapan PBL dipadu jigsaw sebesar 84,2\% dengan kriteria sangat terlaksana. Keterlaksanaan tahapan PBL dipadu jigsaw mengalami peningkatan sebesar 8\% dari siklus I. Penyederhanaan LKM dan pembagian poin diskusi sesuai kelompok membuat alokasi waktu diskusi ahli dan kelompok asal menjadi lebih efisien pada siklus II sehingga setiap tahapan pembelajaran yang direncanakan dapat terlaksana lebih baik di siklus II.

Hasil analisis data terkait kategori penguasaan keterampilan literasi informasi mahasiswa dari pra-siklus hingga siklus II tersaji pada Gambar 3. Berdasarkan Gambar 3 diketahui bahwa penguasaan kategori Mengetahui mengalami peningkatan dari pra siklus ke siklus II sebesar $32,5 \%$ atau naik sebesar $17,5 \%$ dari siklus I ke siklus II.

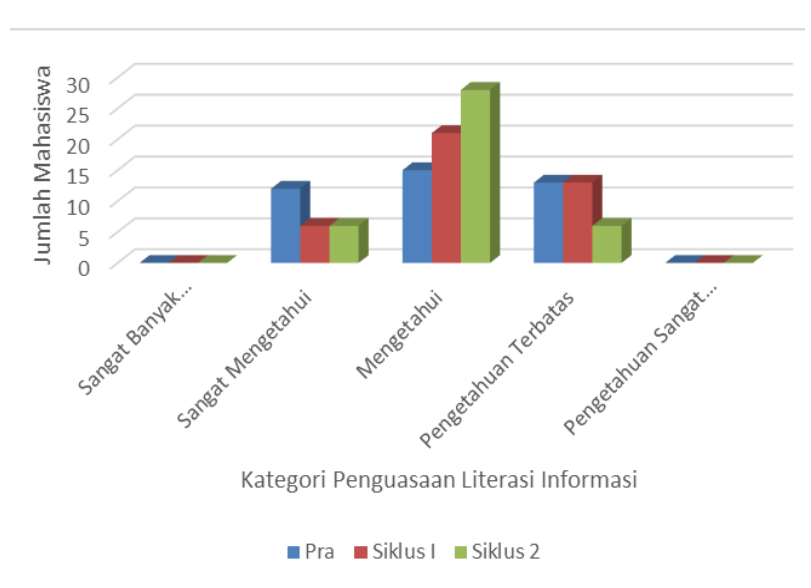

Gambar 3. Perbandingan kategori penguasaan literasi informasi mahasiswa pra-siklus, siklus I dan siklus II.

Kategori Pengetahuan Terbatas mengalami penurunan sebesar $17,5 \%$ dari pra siklus dan siklus I ke siklus II. Sementara itu, kategori Sangat Mengetahui tetap stagnan dari siklus I ke siklus II dan mengalami penurunan sebesar 15\% dari pra-siklus ke siklus II. Selanjutnya, dilakukan analisis terkait kelima indikator literasi informasi yang dapat dilihat pada Gambar 4.

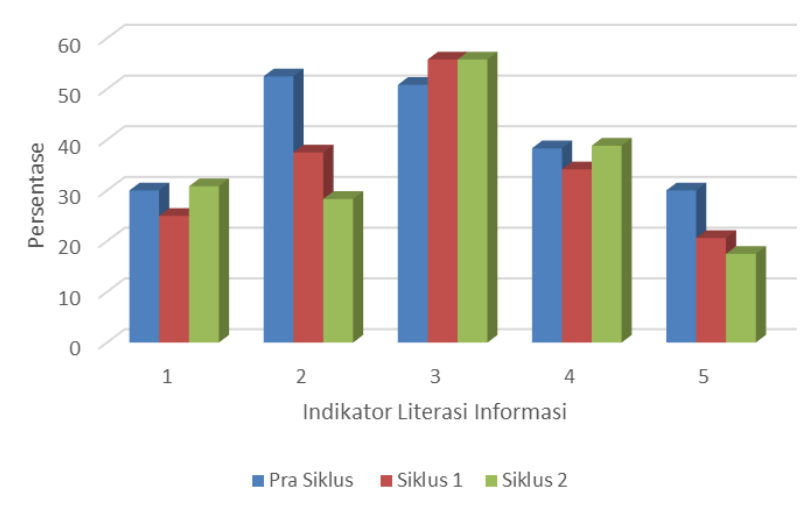

Gambar 4. Persentase penguasaan indikator literasi informasi dari pra-siklus ke siklus II

Berdasarkan Gambar 4, diketahui bahwa indikator literasi informasi yang paling dominan berkembang yaitu indikator mengevaluasi informasi dan sumber dengan kritis dan menggabungkan informasi yang dipilih menjadi dasar pengetahuan. Selanjutnya yaitu indikator mengidentifikasi informasi yang dibutuhkan dan menggunakan informasi secara efektif untuk mencapai tujuan tertentu yang mengalami penurunan pada siklus I menjadi meningkat 
persentasenya di siklus II. Temuan ini sejalan dengan hasil penelitian dan Shultz \& Li (2015) dan Snavely (2004) yang melaporkan bahwa pembelajaran problem based learning memfasilitasi pengembangan keterampilan literasi informasi mahasiswa pada konteks pendidikan tinggi. Aktivitas pemecahan masalah memberikan siswa keterampilan untuk menemukan sumber yang relevan dan menilainya untuk merumuskan solusi dari permasalahan yang ada (Blummer, 2007). Aktivitas kolaborasi pada saat diskusi kelompok ahli dan kelompok asal memfasilitasi mahasiswa secara bersama-sama untuk mengorganisir, mengecek, mengkritisi dan menganalisis informasi (Shonrock \& Crull, 2010) sehingga dapat merumuskan dan menyajikan solusi dari permasalahan yang dirumuskan sebelumnya.

Walaupun demikian, dua indikator literasi informasi mengalami penurunan persentase dari pra-siklus ke siklus II yaitu indikator mengakses informasi yang dibutuhkan secara efektif dan efisien serta memahami isu ekonomi, hukum dan sosial seputar penggunaan informasi serta mengakses dan menggunakan informasi secara etis dan legal. Hal ini berkaitan dengan proses mengonstruk makna dari informasi yang ditemukan dan menggunakan informasi tersebut sesuai etika akademis yang berlaku (ACRL, 2000). Temuan ini mengindikasikan bahwa sintaks dan kegiatan pembelajaran yang dirancang pada penelitian ini belum menekankan pada pentingnya penjelasan dan penekanan terkait etika dan legalitas informasi yang didapatkan untuk merumuskan solusi dari permasalahan yang ada. Shonrock \& Crull (2010) menegaskan bahwa di awal pembelajaran, berbagai isu terkait etika dan legalitas penggunaan informasi harus disampaikan kepada mahasiswa. Selanjutnya, isu tersebut kemudian dievaluasi pada saat menilai laporan dan presentasi terkait rumusan solusi yang dihasilkan mahasiswa. Hal ini menuntut persiapan waktu yang matang untuk mengembangkan konten pembelajaran pada rencana perkuliahan yang akan dilaksanakan (Snavely, 2004).
Paparan pembahasan temuan penelitian ini mengindikasikan bahwa pengembangan keterampilan literasi informasi mahasiswa merupakan proses yang tidak singkat. Periode satu semester merupakan periode singkat untuk mengembangkan kemampuan berpikir tingkat tinggi serta membutuhkan ketekunan dan keberlanjutan untuk mendapatkan hasil yang signifikan (Zoller et al., 2000). Bahkan Cook \& Walsh (2012) melaporkan bahwa upaya peningkatan keterampilan literasi informasi mahasiswa oleh Buehler Library of Elmhurst College diakukan sebanyak 200 sesi setiap tahunnya. Dengan demikian, upaya peningkatan literasi informasi mahasiswa pada konteks pendidikan sains hendaknya dilakukan secara berkesinambungan untuk tiap semester.

\section{PENUTUP}

Penelitian ini bertujuan untuk mengetahui sejauh mana penerapan model PBL dipadu jigsaw dapat meningkatkan keterampilan literasi informasi mahasiswa. Hasil penelitian menggambarkan penguasaan literasi informasi mahasiswa yang mengalami peningkatan yaitu hanya pada indikator mengidentifikasi, mengevaluasi dan menggunakan informasi secara efektif untuk merumuskan solusi pemecahan masalah yang ada.

Implikasi dari penelitian ini yaitu pendidik, yang dalam hal ini berkaitan dengan konteks pendidikan tinggi, perlu menyisipkan aktivitas pemecahan masalah dalam perkuliahannya sebagai upaya pengembangan keterampilan literasi informasi yang sangat penting untuk dikuasai mahasiswa di era teknologi saat ini. Penurunan persentase penguasaan pada indikator mengakses informasi secara efektif dan efisien serta memahami isu ekonomi, hukum, dan sosial terkait penggunaan informasi dalam penelitian ini membuka kesempatan untuk melakukan penelitian lanjutan yang berfokus pada perbaikan rancangan aktivitas pada setiap sintaks pembelajaran agar memfasilitasi pengembangan setiap indikator literasi informasi. 


\section{REFERENSI}

Adawiyah, R., Susilo, H., \& Indriwati, S.E. (2019). Discovery learning with jigsaw II on information literacy and cognitive learning outcomes of high school students. Jurnal Pendidikan Sains, 7(4), 139-144.

Amin, A.H., Corebima, A.D., Zubaidah, S., \& Mahanal, S. (2017). Analisis persepsi mahasiswa dan dosen terhadap motivasi belajar pada perkuliahan Fisiologi Hewan. Jurnal Penelitian Pendidikan Matematika dan Sains, 1(2), 35-44.

Arikunto, S., Suhardjono \& Supardi. (2009). Penelitian Tindakan Kelas. Bumi Aksara.

Association of College and Research Libraries (ACRL). (2000). Information literacy competency standards for higher education. American Library Association. http://www.ala.org/ala/mgrps/divs/acrl/s tandards/informationliteracycompetency.cf $\mathrm{m}$

Blummer, B. (2007). Utilizing WebQuests for information literacy instruction in distance education. College and Undergradtuate Libraries, 14(3), 45-62.

https://doi.org/10.1300/J106v14n03_03

Borchardt, R., Salcedo, T. \& Bentley, M. (2018). Little intervention, big results: intentional integration of informacy literacy into an introductory-level biology lab course. Journal of Biological Education, 53(4), 450462.

https://doi.org/10.1080/00219266.2018.1 494029

Carder, L., Willingham, P., \& Bibb, D. (2001). Case-based, problem-based learning Information literacy for the real world. Research Strategies, 18(3), 181-190.

Chevins, P.F.D. (2005). Lectures replaced by prescribed reading with frequent assessment: enhanced student performance in Animal Physiology. Bioscience Education, 5(1), 1-12.

http://dx.doi.org/10.3108/beej.2005.05000 002

Cook, P., \& Walsh, M.B. (2012). Collaboration and problem-based learning: integrating information literacy into a politica science course. Communications in Information Literacy, 6(1), 59-72.

https://doi.org/10.15760/comminfolit.201 2.6.1.118
Diekema, A.R., Holliday, W., \& Leary, H. (2011). Re-framing information literacy: Problembased learning as informed learning. Library \& Information Science Research, 33(4), 261268. https://doi.org/10.1016/j.lisr.2011.02.002

Epps, W.R. \& Taxakis, B. (2015). Putting the pieces together: How librarians at Campbell University use the Chepalonian and Jigsaw methods to teach information literacy. Georgia International Conference on Information Literacy. 79.

https://digitalcommons.georgiasouthern.ed u/gaintlit/2015/2015/79

Fainburg, L. I. (2009). Information seeking and learning: a comparison of Kuhlthau's information seeking model and John Dewey's problem solving model. New Library World, 110(9/10), 457-466.

Freeman, E. \& Lynd-Balta. (2010). Developing information literacy skills early in an undergraduate curriculum. College Teaching, 58(3), 109-115.

http://dx.doi.org/10.1080/875675509035 21272

Guilford, J.P. (1988). Some changes in Structureof-Intellect Model. Educational and Psychological Measurement, 48(1), 1-4. https://doi.org/10.1177/00131644880480 0102

Harwood, W. S. (2004). A new model for inquiry. Journal of College Science Teaching, 33(7), 29-33.

Hendayana, S. Suryadi, D. Karim, Sukirman, Ariswan, Sutopo, Supriatna, Sutiman, Santosa, Imansyah, H. Paidi, Ibrohim, Sriyati, S. Permanasari, A. Hikmat, dan Nurjanah. (2006). Lesson study suatu strategi untuk meningkatkan keprofesionalan pendidik [Pengalaman IMSTEP-JICA].

Hendayana, S. (2007). Lesson study "suatu strategi untuk meningkatkan keprofesionalan pendidik [Pengalaman IMSTEP-JICA]. UPI PRESS.

Hopkins, D. \& Ahtaridou, E. (2008). A teacher's guide to classroom research. McGraw-Hill Education.

Horton, F. W. (2007). Understanding information literacy: A primer. UNESCO. 
Karmana, I. W. (2010). Pengaruh strategi problem based learning dan integrasinya dengan jigsaw terhadap kemampuan pemecahan masalah, kemampuan berpiir kritis, kesadaran metakognitif, dan hasil belajar kognitif biologi pada siswa kelas $X$ SMA Negeri 4 Mataram [Tesis tidak diterbitkan]. Pascasarjana Universitas Negeri Malang.

Kemmis, S \& Taggart, Mc. (1988). The Action Research Planner. Dakin University.

Kenney, B.F. (2008). Revitalizing the one-shot instruction session using problem-based learning. Reference \& User Services Quarterly, 47(4), 386-391.

Lemons, C. (2009). Replication of significant correlations in small samples. Evaluation \& Research in Education, 22(2-4), 75-86.

Middle States Commission on Higher Education. (2003). Developing research and communication skills: Guidelines for information literacy in the curriculum. Philadelphia, Pa. : Middle States Commission on Higher Education, 11-12. http://www.msche.org/publications/devski 11050208135642.pdf

Ningsih, F., Indriwati, S.E., Ghofur, A., \& Amaliah, N. (2020). Peningkatan keterampilan berpikir kritis mahasiswa melalui penerapan model pembelajaran Learning Cycle 7E berbasis Lesson Study. BIOMA, 2(1), 29-36.

Nurmala, R.S., Corebima, A.D., Ibrohim. (2015). Pengaruh strategi problem based learning dipadu jigsaw terhadap kemampuan berpikir kritis dan hasil belajar kognitif siswa kelas X SMA. Jurnal Pendidikan Sains, 3(3), 130-136.

Oliver-Hoyo, M., \& Allen, D. (2006). The use of triangulation methods in qualitative educational research. Journal of College Science Teaching, 35(4), 42-47.

O'Neil, P.B. (2005). Development and validation of the beile test of information literacy for education (b-tiled) [Disertasi tidak diterbitkan]. University of Central Florida.

Rusman. (2010). Model-model pembelajaran. Mulia Mandiri Press.

Saefi, M. (2017). Pengaruh blended-challenge based learning terhadap kemampuan literasi informasi, berpikir kritis, dan literasi sains pada mahasiswa S1 Pendidikan Biologi Universitas Negeri Malang [Tesis tidak diterbitkan]. Universitas Negeri Malang.
SCONUL. (2011). The SCONUL seven pillars of information literacy.

http://www.sconul.ac.uk/sites/default/files /documents/coremodel.pdf

Shonrock, D.D. \& Crull, S.R. (2010). Information literacy and cooperative learning: a global housing project. Public Services Quarterly, 6(1), 1-18. http://dx.doi.org/10.1080/152289509035 34477

Shultz, G.V. \& Li, Y. (2015). Student development of information literacy skills during problem based organic chemistry laboratory experiments. Journal of Chemistry Education, 93(3), 413-422. https://doi.org/10.1021/acs.jchemed.5b00 523

Snavely, L. (2004). Making problem-based learning work: Institutional challenges. Portal: Libraries and the Academy, 4(4), 521531.

Sugiyono. (2011). Metode Penelitian Pendidikan: Pendekatan Kuantitatif, Kualitatif dan R\&D. Alfabeta.

Wahyuni, E.S. (2015). Implementasi lesson study pada mata kuliah anatomi fisiologi hewan mahasiswa semester III program studi Pendidikan Biologi FKIP Universitas Tanjungpura. Makalah dipresentasikan pada Semirata 2015 bidang MIPA BKS-PTN Barat Universitas Tanjungpura, Pontianak, Kalimantan Barat.

Wallace \& Jefferson. (2013). Developing critical thinking skills for information seeking success. New Review of Academic Librarianship, 19(3), 246-255.

Wenger, K. (2014). Problem based learning and information literacy. Pennsylvania Libraries: Research and Practice, 2(2), 142-154.

Zoller, U., R. Blonder., O.E. Finlayson., F. Bogner., L.Anne K., and Kaiser F.G. (2014). Researchbased coherent science teachingassessment-learning to think for global sustainability. Proceedings of the ESERA 2013 Conference e-Proceedings, Nicosia, Cyprus, 2-7. 